\title{
The Relationship Between Vitamin D Levels and Receptor Activator of Nuclear Factor Ligand in Hashimoto's Thyroiditis
}

\section{Hashimoto Tiroiditinde Vitamin D Seviyeleri ile Reseptör Aktivatör Nükleer Kappa-B Ligandı Arasındaki Illişki}

\author{
Hakan Yavuzer, Selver Işık*, Mahir Cengiz** , ibrahim Murat Bolayırlı***, \\ Alper Döventaş, Deniz Suna Erdinçler \\ istanbul University Faculty of Medicine, Department of Internal Medicine, Division of Geriatrics, Istanbul, Turkey \\ ${ }^{*}$ Dr. Lütfi Kırdar Kartal Training and Research Hospital, Clinic of Medical Oncology, Istanbul, Türkiye \\ **istanbul University Faculty of Medicine, Department of Internal Medicine, Istanbul, Turkey \\ ***istanbul University Faculty of Medicine, Department of Biochemistry, Istanbul, Turkey
}

Abstract

Aim: In order to analyze the relationship of Hashimoto's thyroiditis with vitamin $D$ and osteoclastogenic markers, we investigated vitamin D, osteoprotegerin (OPG) and receptor activator of nuclear factor ligand (RANKL) levels in patients over 60 years with and without Hashimoto's thyroiditis.

Methods: Eighty three female patients (49 with and 34 without Hashimoto's thyroiditis), who attended the endocrinology and geriatrics departments between May 2013 and October 2013 were included in the study.

Results: There was no statistically significant difference in the levels of vitamin D, OPG and RANKL between the groups. Vitamin D was significantly correlated with OPG and RANKL in patients with Hashimoto's thyroiditis. In addition, a significant relationship was found between OPG and RANKL levels. Of the patients with Hashimoto's thyroiditis, 33 were autoantibody-positive and 16 were negative. Vitamin D, OPG and RANKL levels were significantly lower in antibody-positive patients than in negative subjects.

Conclucion: There were no differences in vitamin D, OPG and RANKL levels between patients with and without Hashimoto's thyroidits. Autoantibody-positive Hashimoto's thyroiditis group had statistically significantly lower vitamin D, OPG and RANKL levels. This reverse correlation suggests that autoantibodies may have an effect on osteoclastogenesis.

Keywords: Hashimoto's thyroiditis, vitamin D, receptor activator of nuclear factor ligand
Amaç: Hashimoto tiroiditli 60 yaş üstü hastalarda vitamin $D$ düzeyi ile osteoklastojenik belirteçlerden osteoprotegerin (OPG) ve reseptör aktivatör nükleer kappa-B ligandı (RANKL) düzeylerinin ilişkisini göstermektir.

Yöntemler: Çalışmaya Mayıs - Ekim 2013 tarihleri arasında, endokrinoloji ve metabolizma ile geriatri bilim dallarına başvuran 49 Hashimoto tiroiditli ve 34 Hashimoto tiroiditi olmayan 83 kadın alındı.

Bulgular: Grupların D vitamini, OPG ve RANKL düzeyleri arasında anlamlı fark bulunmadı. Hashimoto tiroiditli grupta, D vitamini ile OPG ve RANKL arasında güçcü ilişki bulundu. Bununla birlikte OPG ile RANKL arasında anlamlı bir ilişki saptandı. Hashimoto tiroiditlilerin 33'ünde otoantikor pozitifliği bulunurken $16^{\prime}$ sında otoantikorlar negatifti. Antikor pozitifliği olan grupta, D vitamini, OPG ve RANKL düzeyleri negatif gruba göre anlamlı olarak düşük bulundu.

Sonuç: Hashimoto tiroiditli grup ile kontrol grubu arasında D vitamini, OPG ve RANKL düzeyi açısından anlamlı farklılık saptanmamıştır. Otoantikor pozitifliği olan Hashimoto tiroiditli grupta D vitamini, OPG ve RANKL anlamlı olarak düşük saptanmıştır. Bu zıt yönlü ilişki, otoantikorların otoimmün tiroidite olduğu gibi, osteoklastojenez üzerine de olumsuz etki yaratabileceğini destekler niteliktedir.

Anahtar Sözcükler: Hashimoto tiroiditi, vitamin D, reseptör aktivatör nükleer kappa-B ligandı
Address for Correspondence/Yazışma Adresi: Hakan Yavuzer

İstanbul University Faculty of Medicine, Department of Internal Medicine, Division of Geriatrics, İstanbul, Turkey Phone: +90 5334534090 E-mail: drhakanyavuzer@gmail.com ORCID ID: orcid.org/0000-0003-2685-6555

Received/Geliş Tarihi: 6 April 2017 Accepted/Kabul Tarihi: 2 May 2017
Copyright 2017 by The Medical Bulletin of University of Health Sciences Haseki Training and Research Hospital
The Medical Bulletin of Haseki published by Galenos Yayınevi.

Telif Hakkı 2017 Sağlık Bilimleri Üniversitesi Haseki Eğitim ve Araştırma Hastanesi Haseki Tıp Bülteni, Galenos Yayınevi tarafından basılmıştır. 


\section{Introduction}

The most common cause of hypothyroidism is still the deficiency of iodine intake all over the world. However, in United States and in areas of iodine deficiency, the most common etiology of hypothyroidism is autoimmune (Hashimoto's) thyroiditis. This disorder, also called as chronic lymphocytic thyroiditis or autoimmune thyroiditis, can be diagnosed in all ages, though most commonly seen in the middle age. The incidence of Hashimoto's thyroiditis is four in every 1000 females and one in every 1000 males per year $(1,2)$. The thyroid gland is infiltrated by the lymphocytes and then, severe damage with disturbance of the hormone production is observed in this disorder (3).

Vitamin D, which is different from other types of vitamins, is synthesized within the body and called as "hormone". It is suggested that vitamin D deficiency had a role in the development of autoimmune disorders, inflammatory bowel disease, romatoid arthritis, multiple sclerosis, diabetes, many types of cancers and cardiac disorders besides the known effects on calcium homeostasis and bone metabolism $(4,5)$. Considering the effects of vitamin D on the immune system, it is suggested that vitamin D may have a role in the pathogenesis of Hashimoto's thyroiditis. In some studies, it was found that vitamin D receptor (VDR) polymorphism increased the incidence of Hashimoto's thyroiditis (6).

A new protein called "osteoprotegerin (OPG)" that inhibits bone resorption was found by two separate research groups in $1997(7,8)$. Then, studies on this issue were accelerated and two different proteins controlling the physiologic and pathologic bone resorption were discovered. One of them called "receptor activator of nuclear factor-kappa B (RANK)" is a receptor found on osteoclasts that cause bone resorption with stimulation (9).

OPG is a member of tumor necrosis factor (TNF) receptor family. However, it does not contain transmembrane and cytoplasmic parts as the other receptors in the superfamily. OPGs, except osteoblasts, are synthesized by hematopoietic and immune cells in many organs such as the kidneys, liver, lungs, spleen, and brain as well as the cardiovascular system (heart, arteries and veins) and bone marrow. The secretion of OPGs is regulated by many cytokines, peptides, hormones and drugs. It was observed that OPGs that were synthesized by the bone marrow cells and were decreased in number by age. Besides this, the tensile force on the bone surface increases the OPG messenger RNA synthesis. All of them suggest that OPG is an important mediator within the scope of senile osteoporosis and bone loss due to immobilization $(10,11)$.

Bone mass is determined by both osteoclasts and osteoblasts. RANK ligand (RANKL), a key mediator of bone resorption in normal and pathological conditions, is a member of TNF ligand family. It is synthesized by osteoblasts in many organs, such as the spleen, and bone marrow but mainly in the lymph nodes, thymus and lungs. The synthesis of RANKL is regulated by many factors such as hormones at transcriptional, translational and posttranslational levels, such as 1.25-dihydroxy vitamin $\mathrm{D}\left[1.25\right.$ hydroxy $\left.(\mathrm{OH})_{2} \mathrm{D}\right]$, growth factors, peptides [transforming growth factor (TGF)-beta 1, fibroblast growth factor-2 and parathyroid hormone (PT)-related protein], cytokines, such as interleukin (IL)-1 beta, IL-6, IL-11 and TNF-alpha, and glucocorticoids. The synthesis of RANKL in osteoblasts/stromal cells is regulated by many factors that stimulate osteoclast formation and activation (12).

The relationship of OPG and RANKL with the immune system has been shown in many studies. The connection of RANKL with RANK increases the vividness of dendritic cells, the capacity to stimulate the immune system and inhibition of the apoptosis $(13,14)$. It provides the activation of c-jun $\mathrm{N}$-terminal of $\mathrm{T}$ cell intrinsic signalling pathway and controls the function of the stimulated $T$ cells. RANKL, which is secreted from the stimulated T cells in the immune system, is needed for the lymphocyte differentiation and lymph node organogenesis. Furthermore, RANKL, like TNF, stimulates the release of immature progenitors into to the circulation (15).

In this study, our aim was to determine the relationship of Hashimoto's thyroiditis with vitamin D levels and osteoclastogenic markers with comparing vitamin D, OPG and RANKL levels between patients with and without Hashimoto's thyroiditis.

\section{Methods}

\section{Informed Consent}

The protocol for sample collection was approved by the İstanbul University, Cerrahpaşa Faculty of Medicine Ethics Committee (number: A-38). The study was carried out according to the requirements of the Declaration of Helsinki. All patients were fully informed of the study procedures before they gave their consent.

\section{Study Population}

Patients enrolled in the study were selected from geriatrics and endocrinology outpatient clinics in the period of January 2013 to September 2013. A total 83 females (49 with the diagnosis of Hashimoto's thyroiditis and 34 without Hashimoto's thyroiditis) were included in this study. Data on demographic characteristics and medical records of the patients were obtained from the patient files. Postmenauposal females more than 60 years old with the diagnosis of Hashimoto's thyroiditis, who attended outpatient clinic controls at least once and 
provided written informed consent, were included in the study.

Females aged 60 years and younger and those with renal dysfunction, liver dysfunction, primary hyperparathyroidism, chronic inflammatory or malabsorptive bowel disorders and malignancy were excluded from the study. Patients using medications for osteoporosis or osteopenia and patients using drugs (barbiturates, phenytoin, isoniazide, rifampicin, ketoconazole, etc.) that affect vitamin D metabolism were also excluded from the study.

The diagnosis of Hashimoto's thyroiditis was made according to thyroid peroxidase (TPO) antibody and thyroglobulin ( $\mathrm{Tg}$ ) antibody levels, thyroid ultrasound measurements and the results of thyroid biopsy (1). Vitamin $D$ status of the patients according to serum 25-hydroxyvitamin D3 $\left[25(\mathrm{OH}) \mathrm{D}_{3}\right]$ levels was accepted as follows: normal: $>30 \mathrm{ng} / \mathrm{mL}$; vitamin $D$ insufficiency: 20$30 \mathrm{ng} / \mathrm{mL}$; vitamin D deficiency: $<20 \mathrm{ng} / \mathrm{mL}$, and severe deficiency: $<10 \mathrm{ng} / \mathrm{mL}(16,17)$.

The Hashimoto's thyroiditis-positive group was divided into two subgroups according to autoantibody levels (antiTPO-positive and anti-Tg-negative). Threshold values for anti-TPO and anti-Tg were accepted to be $35 \mathrm{IU} / \mathrm{mL}$ and $40 \mathrm{IU} / \mathrm{mL}$, respectively.

\section{Biochemical Parameters}

Fasting venous blood samples were drawn in the morning after an overnight fasting (10-12 h). The blood samples were centrifuged for 10 minutes at $4000 \mathrm{rpm}$ at $4^{\circ} \mathrm{C}$. For the determination of OPG, RANKL and $25(\mathrm{OH}) \mathrm{D}_{3}$ levels, serum and plasma aliquots were frozen and stored at $-20^{\circ} \mathrm{C}$ immediately until further analysis. OPG, RANKL and $25(\mathrm{OH}) \mathrm{D}_{3}$ levels were determined by the enzymelinked immunosorbent assay (ELISA) using commercial kits (Hangzhou Eastbiopharm Co., Ltd., Hangzhou, China, catalog numbers: CK-E10880, CK-E90425, CK-E90425, respectively) thyrotrophin-stimulating hormone (TSH), free-T4, calcium, phosphorus, PTH, alkaline phosphatase (ALP), albumin, anti-TPO, and anti-Tg levels were recorded from the patient files.

\section{Statistical Analysis}

Statistical analyses were performed using SPSS 20.0 (SPSS Inc., Chicago, IL, USA) for Windows. All statistical comparisons were performed using paired Student's t-test or unpaired t-test. Unpaired t-test was also confirmed by the Wilcoxon signed-RANK test. All data were expressed as mean \pm standard deviation. Pearson's correlation was used for numerical data. Spearman's correlation coefficient was used for nominal data. A $p$ value of less than 0.05 was considered statistically significant.

\section{Results}

Eighty three female individuals were enrolled in the study. The demographic characteristics and biochemical results of all participants are listed in Table 1.

The mean age of the patients with Hashimoto's thyroiditis and controls was $69.8 \pm 5.2$ years and $70.6 \pm 8$ years, respectively $(p=0.256)$. Within the normal range in both groups, there were no statistical differences between calcium, phosphorus, ALP, PTH and albumin levels. The mean TSH level in the Hashimoto's thyroiditis group was $2.43 \pm 2.24 \mathrm{MIu} / \mathrm{L}$ and $1.5 \pm 0.8 \mathrm{MIu} / \mathrm{L}$ in the control group. The mean anti-TPO level was $199 \pm 272 \mathrm{lU} / \mathrm{mL}$ and the mean anti-Tg level was $240 \pm 581 \mathrm{IU} / \mathrm{mL}$.

The mean $25(\mathrm{OH}) \mathrm{D}_{3}$ level in the Hashimoto's thyroiditis group and control group was $19.5 \pm 15 \mathrm{ng} / \mathrm{mL}$ and $23.8 \pm 19$ $\mathrm{ng} / \mathrm{mL}$, respectively. The mean OPG and RANKL levels in the Hashimoto's thyroiditis group were $3.8 \pm 3.4 \mathrm{ng} / \mathrm{mL}$ and $378 \pm 391 \mathrm{pg} / \mathrm{mL}$, respectively. In the control group, the mean OPG and RANKL levels were $3.7 \pm 3.5 \mathrm{ng} / \mathrm{mL}$ and $483 \pm 411 \mathrm{pg} / \mathrm{mL}$, respectively. There were no significant differences in $25(\mathrm{OH}) \mathrm{D}_{3}$, OPG and RANKL levels between the two groups (Table 2). The ratio of OPG/RANKL was higher in the Hashimoto's thyroiditis group $(0.01 \pm 0.001)$ than in the control group $(0.006 \pm 0.002)$ and the difference was statistically significant $(p<0.001)$.

In the Hashimoto's thyroiditis group, the levels of $25(\mathrm{OH}) \mathrm{D}_{3}$ was significantly positively correlated with OPG and RANKL $(r=0.963, p<0.001, r=0.945, p<0.001$, respectively) (Figure 1,2). In addition, there was a significant positive correlation between the levels of OPG and RANKL $(r=0.953, p<0.001)$ (Figure 3).

\begin{tabular}{|l|l|l|l|}
\hline \multicolumn{3}{|c|}{ Table 1. Demographic and biochemical data of the groups } \\
\hline & $\begin{array}{l}\text { Hashimoto's } \\
\text { thyroiditis } \\
\text { (n=49) }\end{array}$ & $\begin{array}{l}\text { Control } \\
\text { (n=34) }\end{array}$ & $\mathbf{p}^{*}$ \\
\hline Mean age (years) & $69.8 \pm 5.2$ & $70.6 \pm 8$ & 0.256 \\
\hline Calcium (mg/dL) & $9.5 \pm 0.35$ & $9.4 \pm 0.31$ & 0.492 \\
\hline Phosphorus (mg/dL) & $3.6 \pm 0.44$ & $3.6 \pm 0.48$ & 0.975 \\
\hline ALP (U/L) & $72.6 \pm 18.9$ & $83.4 \pm 38.6$ & 0.084 \\
\hline PTH (pg/mL) & $58.6 \pm 21.7$ & $64.7 \pm 23.3$ & 0.121 \\
\hline Albumin (g/dL) & $4.2 \pm 0.28$ & $4.3 \pm 0.26$ & 0.321 \\
\hline Free T4 (ng/dL) & $1.3 \pm 0.25$ & $1.1 \pm 0.15$ & 0.003 \\
\hline TSH (MIU/L) & $2.43 \pm 2.24$ & $1.5 \pm 0.8$ & 0.018 \\
\hline Anti TPO (IU/mL) & $199 \pm 272$ & - & - \\
\hline Anti TG (IU/mL) & $240 \pm 581$ & - & - \\
\hline $\begin{array}{l}\text { ALP: Alkaline phosphatase, PTH: Parathyroid hormone, TSH: Thyroid stimulating } \\
\text { hormone, TPO: Thyroid peroxidase, TG: Thyroglobulin, Free T4: Free thyroxine 4 } \\
* \text { Student's-t test }\end{array}$ & & \multicolumn{3}{|l}{} \\
\hline
\end{tabular}


Although 33 patients in the Hashimoto's thyroiditis group were autoantibody-positive (anti-TPO and/or anti-Tg positivity), autoantibodies were not detected in 16 patients in this group. When Hashimoto's thyroiditis patients were divided into two subgroups according to the presence of autoantibodies, $25(\mathrm{OH}) \mathrm{D}_{3}$, OPG and RANKL levels were significantly lower in the antibody positive-group than in the antibody-negative group ( $p=0.04, p=0.049, p=0.036$, respectively) (Table 3 ).

Anti-TPO was negative in 16 and positive in 33 of the 49 patients with Hashimoto's thyroiditis. In correlation analysis, there was a significant negative correlation between high levels of anti-TPO and $25(\mathrm{OH}) \mathrm{D}_{3}(\mathrm{r}=-0.359$, $p=0.11$ ).

\section{Discussion}

As seen in many autoimmune diseases, interaction of genetic (internal) and environmental (external) factors prepare the ground for the occurance of Hashimoto's thyroiditis. However, it is believed that genetic factors are more relevant in the etiology of disease (18).

In animal models, vitamin $\mathrm{D}$ has been shown to prevent the development of autoimmune thyroiditis effectively (19). It has been suggested that this was provided by inhibition of human leukocyte antige class 2 expression in the endocrine cells (20). With the discovery of the VDRs in mononuclear cells, it has been found that vitamin $D$

\begin{tabular}{|l|l|l|l|}
\hline $\begin{array}{l}\text { Table 2. 25-OH vitamin D, osteoprotegerin and receptor } \\
\text { activator of nuclear kappa B ligand levels of the groups }\end{array}$ \\
\hline & $\begin{array}{l}\text { Hashimoto's } \\
\text { thyroiditis }(\mathbf{n}=49)\end{array}$ & $\begin{array}{l}\text { Control } \\
(\mathbf{n}=\mathbf{3 4})\end{array}$ & $\mathbf{p}^{*}$ \\
\hline $\begin{array}{l}\text { 25-OH vitamin D } \\
(\mathrm{ng} / \mathrm{mL})\end{array}$ & $19.5 \pm 15$ & $23.8 \pm 19$ & 0.270 \\
\hline $\mathrm{OPG}(\mathrm{ng} / \mathrm{mL})$ & $3.8 \pm 3.4$ & $3.7 \pm 3.5$ & 0.888 \\
\hline RANKL $(\mathrm{pg} / \mathrm{mL})$ & $378 \pm 391$ & $483 \pm 411$ & 0.245 \\
\hline $\begin{array}{l}\text { OPG/RANKL (ng/ } \\
\text { pg) }\end{array}$ & $0.01 \pm 0.001$ & $0.006 \pm 0.002$ & $p<0.001$ \\
\hline $\begin{array}{l}\text { OPG: Osteoprotegerin, RANKL: Receptor activator of nuclear kappa B ligand } \\
\text { OH: Hydroxy, *Student's-t test }\end{array}$ & \multicolumn{4}{|l}{} \\
\hline
\end{tabular}

Table 3. Comparison of Hashimoto's thyroiditis group according to autoantibody status

\begin{tabular}{|l|l|l|l|}
\hline & $\begin{array}{l}\text { Antibody } \\
\text { positive }(\mathbf{n}=\mathbf{3 3})\end{array}$ & $\begin{array}{l}\text { Antibody } \\
\text { negative }(\mathbf{n}=16)\end{array}$ & $\mathbf{p}^{*}$ \\
\hline $\begin{array}{l}25-\mathrm{OH} \text { vitamin D } \\
(\mathrm{ng} / \mathrm{mL})\end{array}$ & $17.8 \pm 13$ & $30 \pm 26$ & 0.04 \\
\hline OPG $(\mathrm{ng} / \mathrm{mL})$ & $3.4 \pm 2.5$ & $6.5 \pm 6.4$ & 0.049 \\
\hline RANKL $(\mathrm{pg} / \mathrm{mL})$ & $336 \pm 335$ & $631 \pm 611$ & 0.036 \\
\hline
\end{tabular}

OPG: Osteoprotegerin, RANKL: Receptor activator of nuclear kappa B ligand *Unpaired t-test, Wilcoxon verification test may play a role in the immune regulation mechanism (21). In a study conducted in Taiwan by Lin et al. (6), 90 healthy individuals and 109 patients with Hashimoto's thyroiditis were evaluated and VDR- Fok1 polymorphism in exon two was found to increase the risk of developing Hashimoto's thyroiditis. Ban et al. (22) found that VDRFok1 polymorphism was associated with Hashimoto's thyroiditis in their study conducted on 130 female patients with Hashimoto's thyroiditis. In a study by Pani et al. (23), the $C / T$ polymorphism in vitamin $D 1 \alpha$-hydroxylase gene in intron six was found to be associated with Hashimoto's thyroiditis. In another study from Croatia performed by Stefani et al. (24), 145 patients with Hashimoto's thyroiditis were compared with 145 age-, gender and ethnicity-matched healthy individuals. In this study, the haplotype variants of VDR gene three region and allele imbalance were shown to play a role in the pathogenesis of thyroiditis. In accordance with the literature, we investigated the level of vitamin $D$ to determine the role of vitamin D in the development of Hashimoto's thyroiditis. Mean vitamin D levels in both groups with and without Hashimoto's thyroiditis were lower $(19.5 \pm 15 \mathrm{ng} / \mathrm{mL}$ and $23.8 \pm 19 \mathrm{ng} / \mathrm{mL}$ respectively; $p=0.27$ ) but this was not statisticallysignificant.

Vitamin D deficiency poses a serious health problem in most individuals in Turkey. There are several personal and environmental factors affecting the level of vitamin D. Of these, the most important factor is the season. Turkey is located at the latitude where vitamin D synthesis takes place between the months of May to November. Direct exposure of the skin to sunlight is required for the synthesis. The optimum time for sun exposure for vitamin D production is between the hours 10:00 am and 15:00 pm during the summer (25). For this reason, we examined

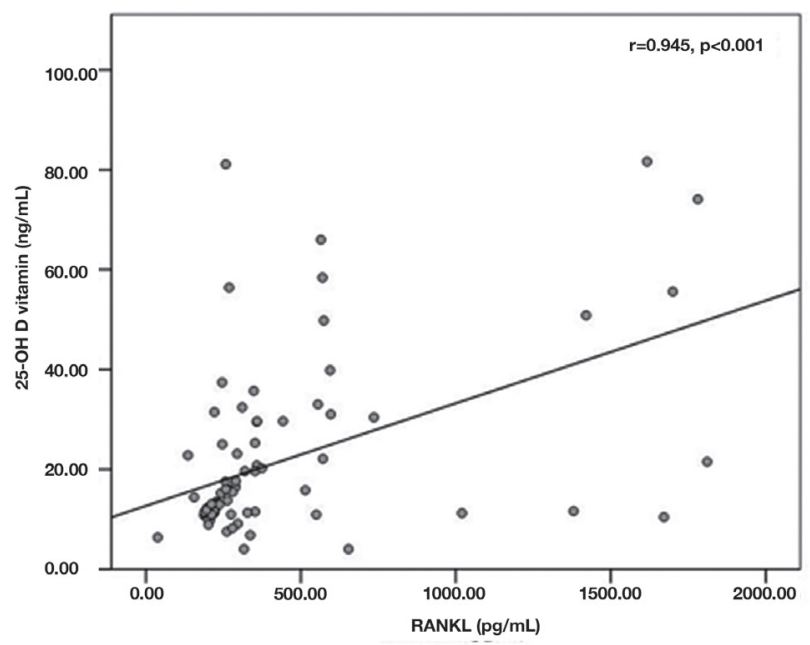

Figure 1. The relationship between $25-\mathrm{OH}$ vitamin $\mathrm{D}$ and receptor activator of nuclear kappa $\mathrm{B}$ ligand RANKL: Receptor activator of nuclear kappa B ligand 
the serum samples of our studied groups between May and November. Clothing style is one of the personal factors affecting the levels of vitamin D. Clothes form a significant barrier preventing the ultraviolet radiation from penetrating the skin. In studies from Arab countries with abundant sunlight, it has been found that traditional clothing might limit potential sun exposure for vitamin $D$ production (26). A majority of the participants in our study group were the people who weared traditional clothing covering most of the skin. This could be another reason for low vitamin $D$ levels in subjects in our study.

A similar study by Bozkurt et al. (27) that was published in May 2013 before our study found that $25(\mathrm{OH}) \mathrm{D}_{3}$ levels were low in both 360 patients with Hashimoto's thyroiditis and 180 healthy controls. Lower levels in the group of Hashimoto's thyroiditis compared to the control

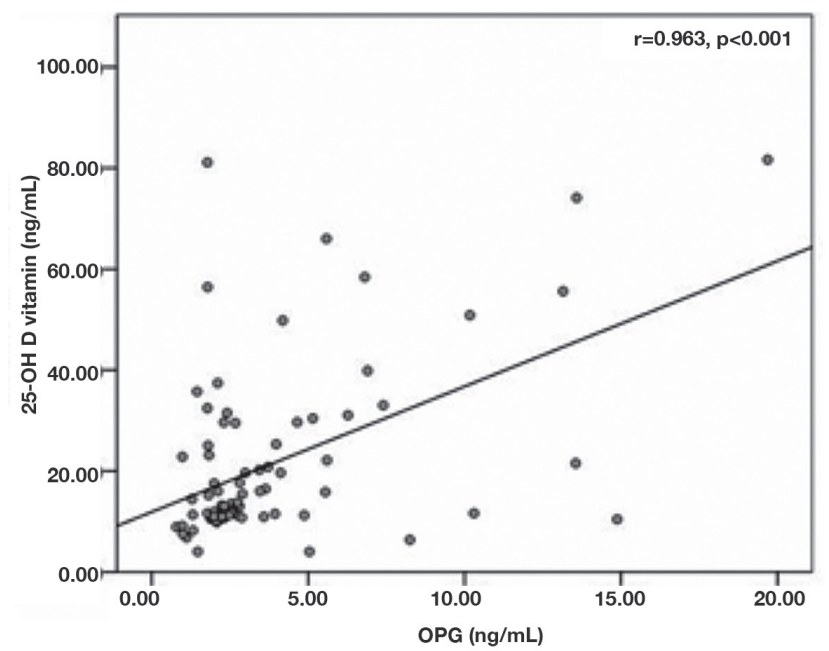

Figure 2. The relationship between $25-\mathrm{OH}$ vitamin $\mathrm{D}$ and osteoprotegerin OPG: Osteoprotegerin

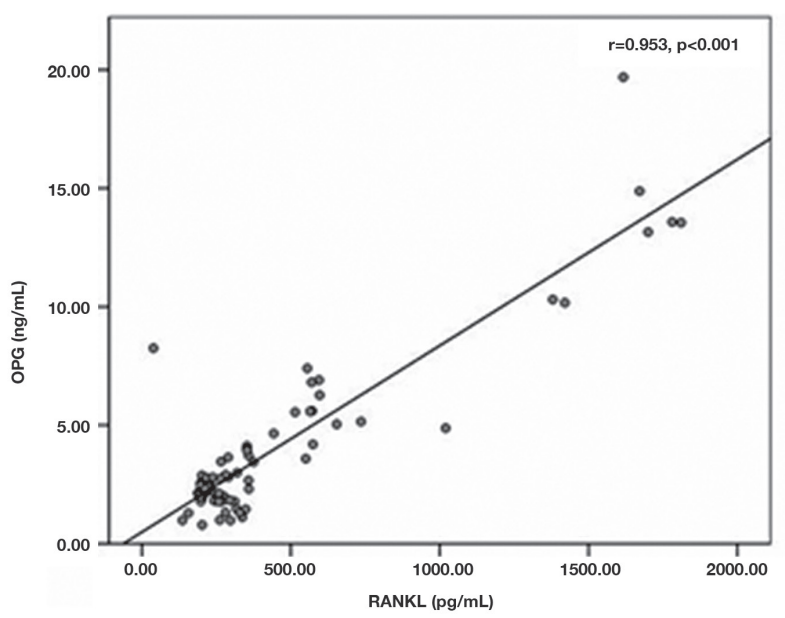

Figure 3. The relationship between osteoprotegerinand receptor activator of nuclear kappa B ligand

OPG: Osteoprotegerin, RANKL: Receptor activator of nuclear kappa B ligand group were pointed out and the relationship of vitamin D insufficiency with the disease period, thyroid volume and antibody levels was emphasized (27). We did not show such a relationship in our study. However, we think that it may be related to the small sample size, limiting the participants to the age group of more than 60 years and our demand to determine an independent relationship apart from the Hashimoto's disease period.

VDR regulates also some of the gene expressions in the osteoblasts. The target genes are shown as in the followings: bone matrix proteins, osteocalcine and osteopontine that are regulated by type 1 collagen which is inhibited transcritionally by $1.25(\mathrm{OH})_{2} \mathrm{D}$ and calcitriol (28). Vitamin D acts on intestines, bones and kidneys to control the calcium level within the normal range. The effect on the bone resorption is sinergistic with the level of PTH. Osteoblasts and stromal fibroblasts bind to the specific receptors together with PTH and $1,25(\mathrm{OH})_{2} \mathrm{D}$.

It stimulates the production of RANKL that is found on the surface of osteoblast cells. RANK ligand stimulates the differentiation of immature osteoclast precursors to mature osteoclasts by binding to the RANK receptors found on immature osteoclasts. OPG, also known as "osteoclast inhbiting factor", protects the bone from excessive resorption by inhbiting the terminal steps of osteoclastogenesis. It blocks osteoclast differentiation, prevents vascular calcification and regulates apoptosis $(26,28)$.

The main task of RANKL within the bone is to accelerate bone loss and resorption by providing osteoclast formation and inhibition of the apoptosis. OPG that is a trap receptor of RANKL, acts as a signalling pathway inhibitor of osteoclast differentiation and proliferation by binding to RANKL; prevents RANKL/RANK inetraction competetively; thus, neutralizes the osteoclastogenic effect of RANKL (29).

It is suggested that OPG/RANKL ratio is the main marker of bone mass. Osteoblasts can change the RANKL quantity synthesized and also, many factors that induce RANKL synthesis regulate the OPG synthesis in osteoblasts. It is known that usually an increase in RANKL levels has been shown to be associated with a decrease in OPG levels $(26,28)$.

Considering the close relationship of vitamin $D$ with RANKL and thereby with OPG, we evaluated the relationship of vitamin D levels with OPG and RANKL in Hashimoto's thyroiditis, an autoimmune disease. OPG and RANKL levels in patients who had Hashimoto's thyroiditis were found to be $3.8 \pm 3.4 \mathrm{ng} / \mathrm{mL}$ and $378 \pm 391 \mathrm{ng} / \mathrm{mL}$, respectively. The mean OPG level was $3.7 \pm 3.5 \mathrm{ng} / \mathrm{mL}$, whereas RANKL level was $483 \pm 411 \mathrm{ng} / \mathrm{mL}$ in the control group. There was no statistical significant difference in $25(\mathrm{OH}) \mathrm{D}_{3}$, OPG and RANKL levels between the groups. 
As emphasized in many other similar articles, it is quite difficult to evaluate OPG and RANKL results clinically because they can be affected by methodological difficulties and comorbidities. Many contradictory results have been reported due to lack of a definite, applicable and simple measurement technique. It seems almost impossible to compare OPG concentrations in different studies because of the presence of monomeric and dimeric forms of OPG. Free OPG level measurements can not show the real level of total OPG, because much of the total form are bound to RANKL or other ligands that would not be evaluated $(30,31)$.

The same condition is the case with RANKL. The bound form of RANKL is more than the free form level. However, commercial markers mostly measure the free RANKL levels. It seems more rational to measure total RANKL levels in order to reflect the tissue production. We used the total RANKL and bound form of monomeric OPG measurements in our study with the aim of reflecting the levels more precisely. Therefore, we considered that our results conflicting with other studies may be related to the methodological differences.

Glucocorticoids, fibroblast growth factor-2 and PTH that decrease OPG/RANKL ratio inhibit OPG, whereas stimulate RANKL synthesis. It is observed that some cytokines such as IL-1 $\beta$, IL-4, IL-6, IL-11, IL-17 and TNF- $\alpha$ increase RANKL synthesis and many factors such as prostaglandin E2, many mesenchimal transcription factors and $1.25(\mathrm{OH})_{2} \mathrm{D}_{3}$ cause bone resorption. Estrogen increases the OPG/RANKL ratio by stimulating OPG synthesis in osteoblastic cells and inhibiting RANKL synthesis. TGF- $\beta$ shows antiresorptive effect by accelerating OPG synthesis $(10,11)$.

A study from China detected that $1.25(\mathrm{OH})_{2} \mathrm{D}_{3}$ can inhibit osteoclastogenesis that is induced by inflammation in romatoid arthritis, and it is indicated that this can be possible with the elevation of the OPG/RANKL ratio by stimulating OPG more than RANKL induction (32).

It is suggested that elevated RANKL levels may cause osteoporosis in patients with multiple sclerosis and elevation of RANKL levels may be due to the immune system activation in this disorder. In this study, it was thought that the increase in OPG levels developed in response to elevated RANKL levels (33). We evaluated the OPG/RANKL ratio in our study because its importance was suggested in many other studies and we found that OPG/RANKL ratio was significantly higher in Hashimoto's thyroiditis patients than in controls $(p<0.001)$. We suggest that this condition may be related to lower levels of vitamin $D$ in patients with Hashimoto's thyroiditis.

In our study, we detected autoantibody positivity (antiTPO and/or anti-Tg) in 33 of patients with Hashimoto's thyroiditis whereas 16 of them were antibody negative. When the patients with Hashimoto's thyroiditis were examined according to the presence of autoantibodies, we found that $25(\mathrm{OH}) \mathrm{D}_{3}$, OPG and RANKL levels were significnantly lower in the antibody-positive group than the negative ones $(p=0.04, p=0.049$, and $p=0.036$, respectively). Anti-TPO was negative in 16 of the 49 patients with Hashimoto's thyroiditis; whereas, 33 of them were anti-TPO-positive. There was a weak, negative correlation between high levels of anti-TPO and levels of $25(\mathrm{OH}) \mathrm{D}_{3}$ with the correlation analysis $(r=-0.359, p=0.11)$. However, there was no statistically significant relationship of antibody levels with $25(\mathrm{OH}) \mathrm{D}_{3}$, OPG and RANKL. It is suggested that antibody-negative group that consisted of only 16 patients may explain the absence of a statistically significant relationship. These findings seem to support that exaggerated autoimmunity may have effects on the levels of $25(\mathrm{OH}) \mathrm{D}_{3}$, OPG and RANKL.

It is known that VDR regulates the expression of many genes expression in osteoblasts. Osteocalcine and osteopontine are among these target genes. $1.25(\mathrm{OH})_{2} \mathrm{D}$ and PTH induce RANKL expression that accelerates osteoclast differentiation and osteoclast activity. Despite that, $1.25(\mathrm{OH})_{2} \mathrm{D}$ is also considered to inhibit osteoclastogenesis by increasing the compansatory OPG synthesis. Our study seems to support this opinion. We assume that with larger samples more significant results can be obtained.

\section{Conclusion}

Consequently, no significant difference was detected in $25(\mathrm{OH}) \mathrm{D}_{3}$, OPG and RANKL levels between patients with Hashimoto's thyroiditis and controls. However, 25(OH) $D_{3}, O P G$ and RANKL levels were found to be significantly lower in the autoantibody-positive Hashimoto's thyroiditis subgroup compared to the negative ones. Thus, it may be suggested that autoantibodies that have a role in the pathogenesis of Hashimoto's thyroiditis might affect the osteoclastogenesis as well.

\section{Acknowledgements}

This work was supported by the Research Fund of Istanbul University (project number: 27311).

\section{Ethics}

Ethics Committee Approval: The protocol for sample collection was approved by the İstanbul University, Cerrahpaşa Faculty of Medicine Ethics Committee (approval number: A-38).

Informed Consent: All patients were fully informed of the study procedures before they gave their consent. 
Peer-review: Externally and internally peer-reviewed.

\section{Authorship Contributions}

Surgical and Medical Practices: S.I., H.Y., Concept: A.D., D.S.E., Design: A.D., D.S.E., Data Collection or Processing: S.I., H.Y., I.M.B., Analysis or Interpretation: M.C., A.D., Literature Search: S.I., Writing: S.I., H.Y.

Conflict of Interest: The authors declare that there are no conflicts of interest.

Financial Disclosure: This work was supported by the Research Fund of İstanbul University (project number: 27311).

\section{References}

1. Jackson IMD, Hennessey JV, Thyroiditis. In: Becker KL, editor. Principles an practice of endocrinology and metabolism. Philadephia U.S: Lippincott Williams \& Wilkins; 1998. p. 4568.

2. Tunbridge WM, Vanderpump MP. Population screening for autoimmune thyroid disease. Endocrinol Metab Clin North Am 2000;29:239-53.

3. ilicin $G$, Unal $S$, Biberoğlu $K$, Akalın $S$, Suleymanlar $G$. iç Hastalıkları cilt 2. 2. Baskı. Ankara: Güneş Kitapevi; 22172219.

4. Hollick MF. Sunlight and vitamin D for bone health and prevention of autoimmune diseases, cancer and cardiovascular disease. Am J Clin Nutr 2004;80(Suppl 6):1678-88.

5. Holick MF Vitamin D: important for prevention of osteoporosis, cardiovascular heart disease, type 1 diabetes, autoimmune diseases, and some cancers. South Med J 2005;98:1024-7.

6. Lin WY, Wan L, Tsai CH, Chen RH, Lee CC, Tsai FC. Vitamin $D$ receptor gene polymorphisms are associated with risk of Hashimoto's thyroiditis in Chinese patients in Taiwan. J Clin Lab Anal 2006;20:109-12.

7. Simonet WS, Lacey DL, Dunstan CR, et al. Osteoprotegerin: a novel secreted protein involved in the regulation of bone density. Cell 1997;89:309-19.

8. Tsuda E, Goto M, Mochizuki SI, et al. Isolation of a novel cytokine from human fibroblasts that specifically inhibits osteoclastogenesis. Biochem Biophys Res Commun 1997;234:137-42.

9. Lacey $\mathrm{DL}$, Timms $\mathrm{E}$, Tan $\mathrm{HL}$, et al. Osteoprotegerin ligand is a cytokine that regulates osteoclast differentiation and activation. Cell 1998;93:165-76.

10. Hofbauer LC. Osteoprotegerin ligand and osteoprotegerin: novel implications for osteoclast biology and bone metabolism. Eur J Endocrinol 1999;141:195-210.

11. Schoppet M, Preissner KT, Hofbauer LC. RANK ligand and osteoprotegerin: paracrine regulators of bone metabolism and vascular function. Arterioscler Thromb Vasc Biol 2002;22:549-53.
12. Blair JM, Zheng Y, Dunstan CR. RANK ligand. Int J Biochem Cell Biol 2007;39:1077-81.

13. Schoppet M, Henser S, Ruppert V, et al. Osteoprotegerin expression in dendritic cells increases with maturation and is NF-kappaB-dependent. J Cell Biochem 2007;100:1430-9.

14. Wong BR, Rho J, Arron J, et al. TRANCE is a novel ligand of the tumor necrosis factor receptor family that activates c-Jun N-terminal kinase in T cells. J Biol Chem 1997;272:25190-4.

15. Wong BR, Josien R, Choi Y. TRANCE is a TNF family member that regulates dendritic cell and osteoclast function. J Leukoc Biol 1999;65:715-24.

16. Adams JS, Hewison M. Update in vitamin D. J Clin Endocrinol Metab 2010;95:471-8.

17. Holick MF, Binkley NC, Bischoff-Ferrari HA, et al. Evaluation, treatment, and prevention of vitamin $D$ deficiency: an Endocrine Society clinical practice guideline. J Clin Endocrinol Metab 2011;96:1911-30.

18. Chistiakov DA. Immunogenetics of Hashimoto's htyroiditis. J Autoimmune Dis 2005;2:1.

19. Fournier C, Gepner P, Sadouk M, Charreire J. In vivo beneficial effects of cyclosporine $A$ and 1,25-dihydroxyvitamin D3 on the induction of experimental autoimmune thyroiditis. Clin Immunol Immunopathol 1990;54:53-63.

20. Hahn HJ, Kuttler B, Mathieu C, Bouillon R. 1,25-Dihydroxyvitamin D3 reduced $\mathrm{MHC}$ antigen expression on pancreatic beta-cell in vitro. Transplant Proc 1997;26:2156-7.

21. Bhalla AK, Amento EP, Clemens TL, Holick MF, Krane SM. Specific high-affinity receptors for 1,25- dihydroxyvitamin D3 in human peripheral blood mononuclear cells: presence in monocytes and induction in $\mathrm{T}$ lymphocytes following activation. J Clin Endocrinol Metab 1983;57:1308-10.

22. Ban Y, Taniyama M, Ban Y. Vitamin D receptor gene polymorphism in Hashimoto's thyroiditis. Thyroid 2002;11:607-8.

23. Pani MA, Regulla K, Segni $M$, et al. Vitamin D 1alphahydroxylase (CYP1alpha) polymorphism in Grave's disease, Hashimoto's thyroiditis and type 1 diabetes mellitus. Eur J Endocrinol 2002;146:777-81.

24. Stefani M, Papi S, Suver M, Glavas-Obrovac L, Karner I. Association of vitamin D receptor gene 3 '-variants with Hashimoto's thyroiditis in the Croatian population. Int J Immunogenet. 2008 Apr;35(2):125-31.

25. Pittas AG, Dawson-Hughes B, Li T, et al. Vitamin D and calcium intake in relation to type 2 diabetes in women. Diabetes Care 2006;29:650-6.

26. Ban Y, Taniyama M, Ban Y. Vitamin D receptor gene polymorphism in Hashimoto's thyroiditis. Thyroid 2002; 11:607-8.

27. Bozkurt NC, Karbek B, Ucan B, et al. The association between severity of vitamin D deficiency and Hashimoto's thyroiditis. Endocr Pract 2013;19:479-84.

28. Kurban S, Mehmetoğlu i. Osteoprotegererin, RANK ve Rank Ligandı. Türk Biyokimya Dergisi 2007;132:178-84. 
29. Tenta R, Panagiotakos DB, Fragopoulou E, et al. Osteoprotegerin and nuclear factor-kappaB ligand are associated with leptin and adiponectin levels, in apparently healthy women. J Musculoskelet Neuronal Interact 2010;10:174-9.

30. Anastasilakis AD, Goulis DG, Polyzos SA, et al. Acute changes in serum osteoprotegerin and receptor activator for nuclear factor-kappaB ligand levels in women with established osteoporosis treated with teriparatide. Eur J Endocrinol 2008; 158:411-5.
31. Chen D, Sarikaya NA, Gunn H, Martin SW, Young JD. ELISA methodology for detection of modified osteoprotegerin in clinical studies. Clin Chem 2001;47:747-9.

32. Dawodu A, Absood G, Patel M, et al. Biosocial factors affecting vitamin $D$ status of women of childbearing age in the United Arab Emirates. J Bios Sci 1998;30:431-7.

33. Kurban S, Akpinar Z, Mehmetoglu I. Receptor activator of nuclear factor kappaB ligand (RANKL) and osteoprotegerin levels in multiple sclerosis. Mult Scler 2008;14:431-2. 